\title{
BUSTER KEATON: UM CORPO PÓS-HUMANO?
}

\author{
BUSTER KEATON: A POST-HUMAN BODY?
}

Diogo Rossi Ambiel Facini'

\begin{abstract}
RESUMO: Neste artigo, discuto a possibilidade de se relacionar as manifestaçôes corporais do ator/diretor de comédia Buster Keaton em seus filmes com o conceito de pós-humano, principalmente sua visâo de novas configuraçôes corporais. Algumas características específicas dessa manifestaçăo corporal de Buster poderiam indicar essa aproximaçâo: um tipo de relaçâo com o seu ambiente, numa espécie de simbiose com objetos, animais e máquinas; uma diluiçấo das identidades e das fronteiras, em um estado constante de "estar-entre"; e uma superaçâo das limitaçōes do humano. A discussăo é organizada em três partes. Em primeiro lugar, introduzo o cinema de Buster Keaton, com o objetivo de apontar algumas características centrais para a análise que se sucede, principalmente com relaçăo à manifestaçăo corporal de seu personagem. Na sequência, sáo pontuadas algumas discussôes sobre o pós-humano, tanto enquanto campo de pesquisas, quanto enquanto termo que indica novas vivências e configuraçóes do humano na contemporaneidade. Por fim, algumas leituras sobre a obra de Keaton sâo empreendidas no diálogo com os debates sobre a pós-humanidade.
\end{abstract}

PALAVRAS-CHAVE: Buster Keaton. Corpo. Pós-humano.

ABSTRACT:In this paper, I discuss the possibility of relating the corporalmanifestations of comic actor/director Buster Keaton in his films with the concept of post-human, mainly its vision of new corporal configurations. Some specific characteristics of this body manifestation of Buster could indicate this approach: a kind of relation with its environment, in a kind of symbiosis with objects, animals and machines; a dilution of identities and boundaries, in a constant state of "being-between"; and an overcoming of the limitations of the human. The discussion is organized in three parts. In the first place, I introduce the cinema of Buster Keaton, with the purpose of pointing out some characteristics which are central for the analysis that is made, mainly with respect to the corporal manifestation of his character. Following are some discussions about the post-human, both as a field of research and as a term that indicates new experiences and configurations of the human in the contemporary world. Finally, some readings on Keaton's work are undertaken in the dialogue with the debates on post-humanity.

KEYWORDS: Buster Keaton. Body. Post-human.

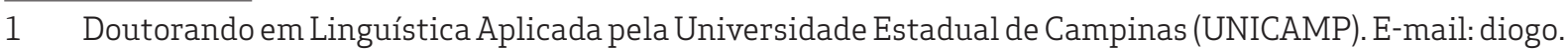
facini@hotmail.com. 


\section{INTRODUÇÃO}

Buster Keaton foi um ator e diretor de comédia americano. Ao lado de Charles Chaplin e Harold Lloyd, faz parte do que poderíamos chamar a tríade da comédia muda, ou seja, os três maiores nomes da comédia do cinema mudo ou silencioso americano. Um dos elementos mais distintivos do cinema de Buster é a sua atuaçăo, que constrói um personagem aparentemente inexpressivo, com um olhar e uma face que se mantém constantes, inabaláveis, nâo importa o contexto em que esteja e nem os sentimentos que o atravessem; isso lhe rendeu alguns nomes ao longo da história, como "stone face" (rosto de pedra), ou "o homem que nunca ri". Além disso, Keaton foi criador de um humor bastante singular, marcado por uma forte fisicalidade e uma relaçáo peculiar com o espaço. Essa fisicalidade se refere principalmente à atuaçáo corporal de Keaton. Uma das características mais notáveis dessa atuaçăo corporal, e que, inclusive, motivou os questionamentos deste artigo, é que, ao trabalhar com o seu corpo, Keaton dá a ele novas configuraçóes, novas identidades, que talvez rompam com uma caracterizaçáo mais natural envolvendo o que seria um corpo "humano".

Retiremo-nos por um instante do cinema, e nos direcionemos ao campo mais amplo das humanidades. A partir do fim do século XX, alguns pesquisadores sentiram que estaríamos atravessando um período de mudanças, que poderiam alterar profundamente a nossa concepçăo do humano. $\mathrm{O}$ desenvolvimento científico, que resultou nos estudos sobre a cibernética, a genética, a informática, a inteligência artificial, parece apontar para novos relacionamentos com o mundo, com as outras pessoas, e mesmo com nós mesmos. E o corpo talvez seja um dos elementos mais afetados por essa transformaçăo, seja existindo em conjunto com próteses ou acessórios, ligado a máquinas ou a redes virtuais: parece que se tornou mais complexo definir o que constituiria um corpo humano, o que indicaria a sua especificidade, a sua singularidade. Talvez a ideia do humano já náo seja suficiente para dar conta dessa situaçăo complexa. Estaríamos caminhando para uma pós-humanidade?

Neste artigo, procuro relacionar algumas manifestaçôes corporais de Buster Keaton a esse campo do pós-humano. Keaton, bem antecipadamente, parece indicar elementos e características de uma relaçăo do corpo com o mundo que podem ser compreendidos como semelhantes a uma situaçăo mais contemporânea, pós-humana. Com seu corpo, Keaton une-se a outros corpos, mistura identidades, rompe fronteiras. A discussāo é construída em três etapas. Em primeiro lugar, apresento e discuto alguns aspectos do cinema de Keaton: sua história, seu uso do corpo, articulaçôes com outros elementos. A seguir, discuto o tema do pós-humano, entendido enquanto situaçăo histórica (ainda em processo) e enquanto possível campo de pesquisas. Por fim, observo alguns elementos mais concretos do cinema de Keaton e reflito sobre essa sua possível constituiçâo corporal pós-humana. Como a abordagem é mais centrada no personagem que em filmes específicos, nâo restrinjo a discussâo a nenhuma obra em especial; apenas destaco o período da década de 1920, considerado o auge do ator/diretor.

\section{O BURLESCO E O CINEMA DE BUSTER KEATON: UM CORPO NO ESPAÇO}

Joseph Frank Keaton, mais conhecido como Buster Keaton, nasceu em 1895 e faleceu em 1966. Iniciou sua carreira nas artes ainda criança, em 1899, como ator de 
vaudeville, trabalhando em conjunto com os pais (SMITH, 2011, p. 67). O apelido Buster foi conferido a ele pelo ilusionista e mestre dos escapes Harry Houdini (COUSINS, 2013, p. 75). Sua carreira no cinema durou quase cinquenta anos. Iniciou-se em 1917, como parceiro de Roscoe "Fatty" Arbuckle, um dos astros da comédia da época. Pode-se considerar que o auge criativo do ator/diretor ocorreu durante os anos 1920, nos curtas e longas-metragens silenciosos dirigidos ou co-dirigidos por Keaton. Jean-Philippe Tessé (2007) chega a afirmar que a carreira de Buster teria durado somente dez anos, de 1920 a 1929, justamente o período mencionado, quando Keaton possuía uma independência e um controle considerável sobre a sua obra. O que ocorreu depois? Em 1928, Keaton assina contrato com a companhia MGM, uma atitude da qual se arrependeria amargamente mais tarde. Perde o controle das obras: sâo impostos a ele atores, técnicos, criadores de piadas; impedem-no de improvisar. Com isso, apesar de um relativo sucesso de público, Keaton entra em um processo de decadência, do qual nunca se recuperaria completamente (TESSÉ, 2007, p. 25-26). Entre os grandes momentos posteriores do ator, podemos citar a sua participaçâo em Luzes da Ribalta (Limelight, 1952), de Charles Chaplin, único filme na história do cinema a trazer Chaplin e Keaton atuando juntos.

De qualquer forma, no período em que pôde atuar criativamente, Buster realizou uma obra fundamental, diferente de todas as outras da comédia da época:

Keaton, ex-acrobata e ator mirim de vaudeville, diferia de Chaplin no sentido de que
sua graça costumava vir do contraste entre seu rosto eternamente inexpressivo e
as incríveis façanhas atléticas que seus personagens precisavam fazer para escapar
do perigo. Com sua execuçáo cuidadosa e desenvolta de sequências cada vez mais
complexas, táo perigosas quanto espetaculares, Keaton aproximava a comédia
física da poesia. (HUNTER, 2011, p. 69).

Podemos iniciar essa discussâo apontando alguns aspectos mais amplos da comédia realizada na época, em que a obra de Keaton se inseria. Cinematograficamente, Buster Keaton se inseria no subgênero cômico do slapstick, ou comédia pastelâo em português, caracterizado por uma velocidade elevada nos movimentos, pela presença constante de perseguiçóes, pela presença de quedas cômicas e muitas vezes de certa violência nas açōes, também com objetivos cômicos. $O$ cinema de Keaton também pode ser inserido em outro grupo, que engloba o slapstick, e às vezes confunde-se com ele. No entanto, ultrapassa a esfera do cinema, podendo-se referir a outras artes, principalmente àquelas do espetáculo: o burlesco. Devido a sua amplitude e à importância do corpo no burlesco, é a ele que me atenho por uns instantes. Jacques Aumont e Michel Marie trazem uma sucinta definiçăo:

[U]m gênero fundado na multiplicaçăo e no encadeamento de piadas, de farsas, geralmente de mal gosto (difamantes, degradantes). No cinema, o burlesco foi um dos primeiros gêneros estabelecidos (desde antes da Primeira Guerra Mundial) e o gênero em que a pantomima cinematográfica fazia maravilhas. Graças ao enquadramento variável (primeiro plano sobre o rosto em que aterrissa a torta de creme), graças à montagem que permite atuaçôes perfeitas e quase sem limite, a arte do cômico de music-hall foi levada à perfeiçáo, e os atores burlescos estiveram entre os maiores dessa geraçăo, de Fatty, Linder e Keaton a O Gordo e o Magro. (AUMONT; MARIE, [2001] 2012, p. 37). 
Dentre as características do burlesco, podemos considerar que umas daquelas que mais se destaca é uma manifestaçâo diferenciada dos corpos na tela:

Ooutrogrande registro corporal [além do corpo monstruoso] que nasceu com o cinema é o burlesco. Na França ele encontrou seu lar, ainda que depois tenha de ser retomado e desenvolvido pelo cinema norte-americano. Ali o corpo age por sobressaltos, ou, antes, pelos sobressaltos da açấo. $\mathrm{O}$ burlesco introduz uma das grandes tradiçóes corporais do cinema, pois o gênero náo funciona através da linearidade da história, mas graças a uma narraçáo dos corpos por cambalhotas sucessivas, descabeladas, onde os fragmentos fazem a confrontaçăo. Essa heterogeneidade remete por outro lado a uma polifonia dos gêneros convocados pela encenaçăo (a acrobacia, a mímica, o teatro, a dança, o desenho) [...], em ritmo de espetáculo onde a interrupçăo, a pausa, o interlúdio, o tombo fazem explicitamente parte do jogo e do prazer. Assim, os heróis burlescos fazem de modo vivamente corporal a experiência de uma "elasticidade narrativa": o corpo do personagem passa por todos os momentos possíveis de uma ideia. (BAECQUE, [2006] 2008, p. 486-487).

É possível observar a importância do corpo no burlesco, mas um corpo específico: sempre em movimento, nunca em repouso, como se habitado por um princípio motor que muitas vezes independe e ultrapassa o personagem, (TESSÉ, 2007, p. 59). Além disso, trata-se de um corpo marcado pelo excesso, seja excesso de falta de jeito, seja de virtuosismo. Esse corpo pratica açôes que perturbam o curso "natural" das coisas, que se opōem à ordem instituída: a gag, algo como uma piada visual no caso desses filmes, é algo inesperado, anormal (p. 55). A exposiçăo do corpo torna-se, no burlesco, praticamente o centro do filme:

[A] própria noçâo de diretor de cinema se tornou entăo inseparável da exposiçăo do próprio corpo, e a tradiçăo burlesca ilustra esse ponto de vista de maneira esplêndida: Max Linder, Charles Chaplin, Buster Keaton, Harold Lloyd encarnam o uso do corpo e a sua exposiçăo ao perigo pelo cineasta, corpo que se tornou o exclusivo e único instrumento de espetáculo. O lugar da obra se tornou o próprio corpo do artista. (BAECQUE, [2006] 2008, p. 488)

E o corpo de Keaton, como se constituiria nos filmes? Uma das características principais desse corpo por si já o ultrapassa: a relaçâo dele com um mundo mais amplo, bem amplo. Segundo Alex Clayton, "o cultivo de um sentido forte de um espaço expansivo fora da tela [...] trabalha para sugerir um mundo maior, mais cheio de possibilidade e perigo, do que qualquer pessoa sozinha poderia conceber ou pesquisar ${ }^{2 \prime}$ (CLAYTON, 2007, p. 46). Ainda segundo Clayton, "a grandeza dos ambientes dos filmes de Keaton é usada para um efeito expressivo através de sua relaçáo com o corpo diminuto do ator ${ }^{3 "}$ (p. 46). Isso provoca efeitos bastante específicos, que diferenciam o seu cinema daquele dos contemporâneos: "Ao reduzir o corpo a uma figura através da escala, e ao colocá-lo dentro de uma vasta localidade impessoal, a comédia de Keaton é tingida de certa frieza fascinante que náo é encontrada, por exemplo, na representaçâo de Chaplin das

2 Traduçăo minha de: "the cultivation of a strong sense of offscreen space [...] works to suggest a world larger, more full of possibility and hazard, than any single person could conceivably survey or account for". As traduçōes posteriores foram todas realizadas por mim.

3 “[...] the largeness of Keaton's environments is used to expressive effect through its relation to the diminutive body". 
relaçōes corpo-mundo ${ }^{4 "}$ (p. 47). Essa relaçăo com o mundo aponta para um elemento fundamental desse corpo de Keaton: "Keaton destaca a colocação espacial do corpo dentro de uma composiçăo e se deleita com o contraste de movimento e quietude, cálculo e aleatoriedade, proximidade e profundidade ${ }^{5 \prime}$ (p. 49). Philipe Tessé comenta que muito já foi dito sobre a "arte do espaço" de Keaton e do esplendor geométrico de seu estilo. Para o autor, "Keaton tem o gosto muito americano dos grandes espaços e as cenas externas deslumbram pela sua maneira de fazer vibrar os elementos 6" (TESSÉ, 2007, p. 26). O autor, que aponta uma "dimensăo cósmica" do cinema de Keaton, continua:

O quadro da açăo é imenso, ele oferece uma multidăo de potencialidades que o cineasta e o ator exploram como topógrafos: cada gag repousa sobre a relaçấo do corpo com o espaço, relaçáo essa que se modula segundo o que Buster sente fisicamente e afetivamente. Dito de outra maneira, cada gag é um estudo do espaço sob o aspecto do afeto7. (TESSÉ, 2007, p. 26-27).

Tessé desenvolve mais um pouco as consideraçōes. Para o autor, no cinema de Keaton, "o espaço náo é unívoco, mais apresentado em todas as suas dimensóes, que se manifestam segundo a necessidade dramatúrgica do instante. [...] Há no cineasta a tentaçăo permanente de experimentar todas as possibilidades do espaço ${ }^{8 \prime}$. Desse modo é possível observar que a relaçăo de Keaton com o ambiente que o cerca é bastante rica e complexa: o personagem năo estabelece uma relaçâo única com o seu entorno, atualiza as suas reaçôes de acordo com as circunstâncias e as possibilidades oferecidas. Essa açăo é realizada principalmente pelo corpo, um corpo adaptativo, dinâmico, que năo se limita a uma essência ou a um modelo. Na terceira seçấo, continuaremos as discussōes sobre a obra de Buster Keaton, enfatizando algumas articulaçōes mais específicas do seu corpo. No momento, podemos observar que o corpo de Buster se manifesta entre corpos, abre-se a esses corpos, mistura-se a eles, o que pode produzir novas configuraçóes, dependendo dos contatos estabelecidos. Essa abertura a novas configuraçôes do corpo é encontrada também nas concepçōes relacionadas ao pós-humano. E é a essas concepçōes que nos dirigimos agora.

\section{PÓS-HUMANO: NOVAS QUESTÕES E CONFIGURAÇÕES DO CORPO}

Primeiramente, devemos deixar claro que o termo pós-humano, ao menos neste artigo, pode se referir a dois elementos relacionados, mas diferentes. Em

4 "In reducing through scale the body to a figure, and placing it within a vast impersonal locale composed with geometrical precision, Keaton's comedy is tinged with a certain fascinating coldness that is not found, for instance, in Chaplin's rendering of body-world relations".

5 "Keaton lays stress on the body's spatial placement within a composition that takes in the contrast of movement and stillness, calculation and randomness, nearness and depth".

6 « Keaton a le goût très américain dés grands espaces et les scènes en extérieur éblouissent par leur manière de faire vibrer les éléments »

7 « Le cadre de l'action est immense. Il offre une multitude de potentialités que le cinéaste et l'acteur explorent en arpenteurs : chaque gag repose sur le rapport du corps à l'espace, rapport qui se module selon ce que Buster éprouve physiquement et affectivement. Autrement dit, chaque gag est une étude de l'espace sous l'aspect de l'affect ».

8 «l'espace n'est pás univoque, mais présenté dans toutes ses dimensions, qui se manifestent selon la nécessité dramaturgique ou expressive de l'instant ». 
primeiro lugar, a uma condiçăo pós-humana; ela seria resultado de uma situaçăo ou de um processo histórico pelo qual a humanidade está passando, que nảo está concluído, e do qual năo se sabe exatamente quais serâo as consequências. Entre as mudanças ocorridas, temos o desenvolvimento em áreas como a genética, que permitiriam uma manipulaçăo praticamente artificial dos organismos vivos, e da cibernética, com o surgimento de redes informáticas cada vez mais complexas; inteligências artificiais aproximam-se das humanas, e estabelecem contatos mais complexos com as pessoas. E há uma diluiçấo das fronteiras entre o homem e a máquina, com o desenvolvimento de próteses e conexóes das mais diversas, que muitas vezes se tornam parte do próprio corpo dos indivíduos. Além dessa situaçáo, podemos considerar que o pós-humano ou pós-humanismo indica um campo de pesquisas, que reúne pesquisadores de áreas diversas em torno da reflexăo sobre essa condiçâo pós-humana e as novas articulaçóes e existências do homem. Essas discussôes podem levar muitas vezes a uma problematizaçăo da posiçấo central do homem nas pesquisas, em direçăo a um posicionamento mais dinâmico e em comunicaçăo com outros elementos e seres, como animais, objetos, máquinas e redes de informação. Quando me refiro a pós-humano neste artigo, englobo, de certa forma, esses dois lados da questâo, com as suas particularidades: tanto o aspecto mais prático relacionado à condiçâo do pós-humano, quanto as possibilidades de reflexâo e compreensâo advindas do campo de pesquisa. Sempre em relaçăo com o tema do corpo, central neste artigo.

Lucia Santaella comenta essa mudança recente e alguns de seus resultados:

O potencial para as combinaçóes entre vida artificial, robótica, redes neurais e manipulaçăo genética é tamanho que nos leva a pensar que estamos nos aproximando de um tempo em que a distinçăo entre vida natural e artificial năo terá mais onde se balizar. De fato, tudo parece indicar que muitas funçôes vitais serăo replicáveis maquinicamente assim como muitas máquinas adquirirăo qualidades vitais. $\mathrm{O}$ efeito conjunto de todos esses desenvolvimentos tem recebido o nome de pós-humanismo. Sob essa denominaçăo, as distinçôes entre o artificial e o natural, o real e o simulado, o orgânico e o mecânico têm sido levadas ao questionamento [...]. (SANTAELLA, [2003] 2004, p. 199).

Desse modo, a noçăo do que constitui o homem se complica, começa a ser questionada: as antigas separaçôes entre natural e artificial, homem e mundo perdem o sentido. As fronteiras que separavam e delimitavam o que era o homem parecem se borrar. Santaella, que afirma que estamos atravessando uma "profunda crise de identidade" (p. 207), discute:

Sabe-se, desde Freud, que o subjetivo é uma construçăo. Năo obstante a complexidade do processo dessa construçăo, ela se sustentava sobre a ilusăo de limites corporais mais ou menos estáveis. O desencarnamento da subjetividade provocado pelas novas tecnologias tirou o chăo dessa ilusăo de estabilidade.

O resultado de tudo isso é profundamente perturbador. O corpo humano está, de fato, sob interrogaçáo. As respostas que têm surgido para as interrogaçóes oscilam entre a utopia e a distopia [...]. (SANTAELLA, [2003] 2004, p. 207).

Com isso, observamos que esse questionamento do humano impacta profundamente nas concepçóes e visôes sobre o corpo humano. Yves Michaud comenta sobre as novas fronteiras desse corpo: "sentimos que nossos corpos náo têm mais exatamente 
os mesmos contornos que antigamente. Já năo sabemos muito bem quais săo os seus limites, o que é possível ou lícito, o que pode ser mudado no corpo sem que mudemos de identidade ou năo" (MICHAUD, [2006] 2008, p. 552). O autor reforça que a perspectiva pós-humana "póe em xeque e em crise as certezas em matéria de identidade e de autocerteza" (p. 562). Podemos perceber por essas citaçóes que a questăo da identidade é fundamental no campo do pós-humano. A autocerteza, ou, em outros termos, a certeza que temos de ser quem somos ou ao menos a ideia que temos de nós mesmos, é abalada. Já náo se sabe exatamente o que seria específico do humano, quando os contatos e misturas com outras esferas o tornam quase indistinguível. Erick Felinto e Lucia Santaella, em uma discussấo mais específica sobre a cibernética, desenvolvem a questăo:

A analogia proposta entre o funcionamento do orgânico e do maquínico arrancou o humano do privilégio de sua irredutibilidade. Surgiu, assim, uma nova maneira de pensar o humano como um sistema de processamento de informaçáo que apresenta similaridades com qualquer máquina dotada de inteligência. (FELINTO; SANTAELLA, 2012, p. 27).

Desse modo, podemos considerar que a questăo pode ir além de uma diluiçấo ou problematizaçâo das fronteiras entre o homem e outros componentes, entre os quais as máquinas: o próprio homem pode ser pensado em termos maquínicos, ou seja, pode ser compreendido tomando-se como base as regras e os elementos de funcionamento de uma máquina. Em um sentido extremo, o homem pode ser pensado como mais uma das máquinas, com uma estrutura específica, mas específica como podem ser específicas todas as máquinas. Nesse sentido, o corpo adquire novas configuraçóes, manifesta-se em novas possibilidades. Trata-se de um corpo híbrido, múltiplo, em diálogos constantes com os mais diversos elementos, que pode se transformar dependendo das necessidades. Um corpo que năo está mais tăo separado dos outros seres e processos, já que inserido em uma rede mais ampla de comunicaçôes.

Esse seria, ao menos na leitura do pós-humano presente neste artigo (há algumas), um caminho para se pensar o corpo pós-humano. Antes de encerrar esta reflexăo, no entanto, gostaria de enfatizar algumas possíveis significaçóes e possíveis ambiguidades do pós-humano. Um olhar apressado poderia indicar que estaríamos caminhando para uma negaçấo da humanidade, ou mesmo a sua destruiçấo ou substituiçấo por formas mecânicas ou informáticas de existência. $O$ "pós" do humano náo indica o surgimento de uma era que negue a anterior, que construirá algo completamente novo sobre um terreno arrasado; o termo indica, em minha compreensăo, um "mais" para o humano, talvez um "além" do humano, mas um "além" que nâo elimine completamente alguns elementos anteriores. Trata-se de um pós-humano no sentido mais crítico do termo, abordagem comentada por Felinto e Santaella (FELINTO; SANTAELLA, 2012, p. 39-44), que náo aceita tăo passivamente ou inocentemente as novidades trazidas com as máquinas e com a informática, e que aponta os possíveis conflitos existentes nesses novos contatos do humano e do seu corpo; mas que também năo nega completamente as novidades, com uma visáo possivelmente alarmista ou apocalíptica dos novos tempos ${ }^{9}$.

E săo justamente essas configuraçóes e manifestaçôes diferenciadas do corpo que observamos na próxima seçâo, dedicada a alguns exemplos do cinema de Buster

9 O termo "apocalíptica" é trazido por Felinto e Santaella (2012, p. 35-36). 
Keaton e à sua atuaçấo corporal. Discuto a seguir algumas articulaçóes do corpo de Keaton, que sâo separadas e classificadas em funçấo do tipo de relacionamento que esse corpo estabelece com outros elementos e "corpos". Sem em nenhum momento pretender estabelecer alguma tipologia definitiva ou única, que dê conta de toda a obra de Keaton, trago três grupos de manifestaçóes corporais do ator, que explicarei a seguir: corpo-com, corpo-entre, e corpo-além.

\section{BUSTER KEATON: CORPO-COM, CORPO-ENTRE, CORPO-ALÉM}

A primeira das articulaçóes/manifestaçôes do corpo de Keaton é a do "corpo-com". Mas o que quero dizer com isso? Nesse tipo de articulaçăo, destaco as junçôes ou acoplamentos do corpo "original" de Keaton com objetos ou máquinas, principalmente as últimas. A aproximaçăo com o campo do pós-humano se dá principalmente quando pensamos nas múltiplas próteses e ligaçóes possíveis nos dias de hoje, às vezes fundamentais para a vida das pessoas, que nos fazem questionar os limites e as possibilidades do corpo humano.

O exemplo que mais se destaca dessa articulaçăo corporal está presente naquele filme que é provavelmente o mais lembrado de Keaton nos dias de hoje: The General $(1926)^{10}$. A obra, inserida em inúmeras listas de melhores filmes ou melhores comédias de todos os tempos, traz, como um de seus elementos centrais, a relaçăo entre o personagem de Keaton e uma locomotiva, chamada A General ${ }^{11}$. Laurent Jullier e Michel Marie trazem algumas informaçóes importantes sobre a obra:

A General năo é apenas mais uma comédia. É também um filme de reconstituiçăo histórica sobre a Guerra de Secessâo [...]. Certamente, tudo é contado do ponto de vista de um modesto maquinista, Johnnie Gray, que tem por único objetivo recuperar aquela que ele mima carinhosamente (A General) e ao mesmo tempo conquistar o coraçáo da bela Annabelle. Ele atravessa toda a Guerra de Secessăo e os campos adversários [...]. (JULLIER; MARIE, [2007] 2009, p. 84).

A estrutura simétrica do filme é destacada pelos autores, que apresentam um pouco do seu enredo:

Na primeira parte, após o prólogo em Marietta [cidade do personagem], em tempo de paz, o filme descreve a fuga da General, conduzida pelos espiōes do Norte e perseguidos por Johnnie. A segunda parte se inicia com a chegada de Johnnie e Annabelle de manhă cedo, em uma estaçáo onde está acampado um regimento do Norte que carrega os vagóes com sacos. Johnnie, enfim, retoma a General e embarca Annabelle escondida em um saco de juta. [Mais ao fim da obra, há o] retorno do herói a Marietta, que provisoriamente encontrou a paz e escapou da ofensiva do Norte [...]. (JULLIER; MARIE, [2007] 2009, p. 84-85).

10 Utilizei para a observaçâo dos filmes a coleçăo Buster Keaton, lançada pela distribuidora Obras Primas do Cinema em 2017, com 8 DVDs, que contém praticamente toda a obra da fase mais criativa de Buster. Nessa coleçâo, alguns filmes aparecem com título em português, enquanto outros (provavelmente nâo lançados de maneira oficial no Brasil anteriormente) aparecem com títulos em inglês. A fim de manter uma padronizaçâo, optei por usar neste artigo apenas os nomes originais, em inglês.

11 Daí o nome do filme, e que em português se chama A General, e náo "O general", como talvez possa ser sugerido em um olhar mais apressado. 
Como se pode observar, o filme trata basicamente do resgate por Buster da sua locomotiva roubada. Ian Haydn Smith (2011, p. 66) aponta que haveria um triângulo amoroso no filme, entre Keaton, A General e Annabelle, e năo creio que essa afirmaçấo seja exagerada: o relacionamento entre Keaton e a General é de proximidade, de diálogo, até mesmo de harmonia. Para Alex Clayton (2007), Keaton demonstra nesse filme como uma harmonia positiva entre homem e máquina pode conduzir à comédia. Na visăo do autor, "o herói de Keaton deve atuar em uníssono com a locomotiva a vapor [...] A força do trem é aliada à sua engenhosidade, a velocidade do trem à sua destreza ${ }^{12 "}$ (CLAYTON, 2007, p. 96). Vale enfatizar aqui essa "junçăo de forças" na relaçăo máquina-Keaton: náo se trata somente de uma uniáo entre corpos, mas uma uniâo que aproveita o melhor do que cada um tem a oferecer. Nessa relaçăo simbiótica, pode-se dizer que os dois elementos ganham algo: a locomotiva consegue sua energia e consegue ultrapassar obstáculos pelo caminho graças aos esforços de Keaton, e Keaton ganha uma velocidade impossível para seu corpo isolado. Ao menos por alguns momentos, talvez seja até possível dizer que nâo haja dois elementos, mas uma junçâo, um homem máquina, e o filme indica essa questăo em uma cena: Buster, sobre o teto da locomotiva, adota uma postura rígida, estática, meio inclinada para a frente, observando o horizonte à sua frente. $\mathrm{O}$ corpo do personagem, a partir de sua gestualidade, e graças ao ângulo lateral da filmagem, torna-se quase uma extensăo da máquina, um prolongamento de sua estrutura: Keaton-locomotiva. É fundamental apontar, no entanto, que essa relaçăo náo implica uma negaçáo completa de Keaton. Assim como apontado acima, trata-se de uma relaçâo de harmonia, em que ambas as partes trazem as suas potencialidades para a obtençâo do resultado final. Como argumenta Clayton (2007, p. 98), o seu corpo năo é um anexo robótico estúpido, sem mente ${ }^{13}$.

Esse olhar mais positivo de Keaton com relaçâo às máquinas e possíveis acoplagens do corpo com outros elementos aparece também em outras obras. No filme The Navigator, de 1924, a relaçăo mais ampla de Keaton agora é com um navio, mesmo que năo tăo afetuosa como em The General. Keaton chega a implementar um pequeno sistema mecânico na cozinha do navio, movido por fios e objetos diversos, para facilitar a sua vida. Também nesse filme, Keaton, em dado momento, precisa mergulhar para arrumar o seu navio. Veste-se de mergulhador, com uma roupa pesada e que parece desconfortável, mas, assim como no caso da General, a relaçấo do apetrecho com o seu corpo é harmônica: Keaton tira do acessório o seu melhor. De modo semelhante ao caso da cozinha do navio, a questăo da casa moderna aparece em alguns outros momentos da obra de Keaton: Em The Scarecrow, de 1920, também temos uma cozinha equipada com uma parafernália de fios, que fazem com que os personagens năo precisem se locomover para utilizar os utensílios. Mas essa modernizaçáo também pode ser um pouco desastrosa: em One Week, de 1920, temos uma casa "montável", que, para grande

12 "Keaton's hero must act in unison with the steam machine [...] The train's strength is allied with his ingenuity, its speed with his dexterity".

13 Essa relaçăo mais harmônica, positiva, entre corpo e máquina em Keaton faz com que haja uma diferença considerável entre a representaçâo de Keaton e aquela realizada por Chaplin em outra obra célebre, Tempos Modernos (Modern Times), de 1936. A postura de Chaplin com relaçấo às máquinas caminha em um sentido muito mais crítico, até mesmo negativo, em relaçâo a possíveis benefícios da máquina. Pode-se dizer que, enquanto Keaton aceita o diálogo corpo máquina, Chaplin o rejeita justamente por um possível caráter opressor e desumanizador, ao menos nos usos representados no filme (no espaço da fábrica). 
comicidade, náo é montada de maneira muito satisfatória. Em The Eletric House, de 1922, o personagem de Keaton equipa toda uma casa com um sistema elétrico, que acaba sendo sabotado por um adversário. Mesmo nos casos em que o resultado da mecanizaçăo ou transformaçăo da casa năo é positivo, é interessante observar a recorrência das representaçóes. Temos aqui visôes quase futuristas sobre a relaçăo da tecnologia com a vida doméstica, algo próximo das criaçôes (já náo tâo futuristas) das casas inteligentes dos dias de hoje, que implicam uma relaçăo própria do corpo humano com sistemas mecânicos e informáticos. Por fim, ressalto que a relaçáo simbiótica, quase amorosa, de Keaton, com outros corpos nâo humanos năo se dá unicamente com seres inanimados. Em Go West (1923), Keaton torna-se amigo de uma vaca, a quem ele protegerá durante toda a obra. O que se destaca na obra é que, assim como em A General, Keaton dá mais afeto a esses seres năo humanos que às próprias pessoas, com exceçâo talvez dos seus pares amorosos.

A seguir, temos a articulaçấo do corpo de Keaton que nomeio "corpo-entre". Nesse caso, procuro destacar determinadas manifestaçôes de Keaton que enfatizam um diluir das fronteiras, principalmente com relaçâo à sua identidade. Determinadas manifestaçôes de seu corpo mostram que ele năo traz uma verdade ou uma essência imutável; os sentidos que esse corpo produz dependem das articulaçôes desse mesmo corpo, que podem ser várias. Como aponta Clayton (2007, p. 56), parece haver certa indeterminaçăo na relaçăo de Buster com o mundo social: o seu personagem parece muitas vezes alheio às divisóes que constituem o mundo; como as suas açôes se orientam frequentemente em funçâo de um olhar mais físico, espacial, com relaçăo ao mundo, outras formas de hierarquia năo parecem fazer tanto sentido para Buster. Os possíveis rótulos e "essências" ligados ao personagem săo muitas vezes frutos de uma disposiçấo particular do seu corpo no tempo e no espaço, o que implica, obviamente, que podem mudar facilmente:

[U]ma nova identidade é impingida a Buster como uma questăo de como se aparece, o que ele está usando, onde ele está. A identidade social é mostrada como radicalmente circunstancial, como nada mais do que a colocaçáo e a aparência do corpo em um determinado ponto no tempo. (CLAYTON, 2007, p. 58).

Como exemplo dessa articulaçăo do corpo, cito o filme The Paleface, de 1922, que retrata a relaçăo e os conflitos de Buster com uma tribo de índios que defendia suas terras das investidas de empresários do petróleo. Em determinada cena, Buster, incorporado a uma tribo indígena como um verdadeiro habitante, estava vestido com uma indumentária indígena, e, rendido por um "homem branco", é obrigado a trocar de roupas com ele a fim de que o homem banco possa passar despercebido pelos índios. O problema é que Buster, agora vestido como um homem "da cidade", é observado à distância pelos índios. Os índios năo o reconhecem, e o atacam. Conforme argumenta Clayton, "à distância, o corpo é despojado da personalidade que ele encarna" (CLAYTON, 2007, p. 60). Desse modo, pode-se considerar que é a "externalidade" do corpo que confere a identidade, e essa "externalidade" pode ser moldada, alterada, ou mesmo distorcida. Essa questâo da distância do corpo colabora para a criaçăo de uma presença forte de construçóes geométricas e mesmo abstratas nos planos de Keaton: de algum modo, a sua relaçấo mais espacial com o mundo o liberta das contingências da vida cotidiana, em sociedade. Nấo há fronteiras, quando as únicas divisóes sâo aquelas que delimitam o espaço. 
Com relaçăo ainda às fronteiras, no início de The Paleface, Buster, caçando borboletas, entra no território indígena; ele năo sabe que os índios, com raiva após serem enganados pelos empresários, haviam dito que matariam o primeiro homem branco que entrasse. Além de tudo, ao entrar, Buster fecha e tranca os portōes. Ele também demora a entender quando é capturado pelos índios. No entanto, năo se trata de idiotice, mas mais de uma inocência do personagem: para ele, as fronteiras simplesmente năo fazem sentido. Pode-se dizer que algo parecido ocorre em outra obra de Keaton, Neighbors, de 1920. Keaton é apaixonado por sua vizinha, que habita uma residência separada da sua por um muro; muro esse que divide o conjunto das habitaçóes exatamente ao meio (o que é enfatizado pelos enquadramentos, que criam uma forte simetria). No entanto, Buster está sempre atravessando as fronteiras, deslocando-se de um "território" a outro (a contragosto dos demais, com exceçâo da namorada, já que as famílias eram "inimigas"). A questâo, assim como em The Paleface, nâo é que ele nâo tenha inteligência para compreender as divisôes do mundo: simplesmente a sua relaçăo com esse mundo é diferente, de outro tipo. A citaçăo a seguir pode nos ajudar a compreender um pouco mais essa questăo:

Grande parte do prazer da comédia de Keaton surge da sua capacidade de revelar o mundo náo como um meio social ou local situacional, mas como uma arena física, onde a relaçấo imediata do corpo com as características topográficas constitui a relaçăo primária entre o eu e o mundo ${ }^{14}$. (CLAYTON, 2007, p. 61).

Por fim, temos a última articulaçăo do corpo de Keaton, que denomino corpo-além. Como o próprio nome indica, aqui considero principalmente os momentos em que Keaton ultrapassa as suas limitaçôes mais humanas e chega a outro patamar. A tendência à abstraçăo acima já parece indicar esse elemento, já que aponta para uma superaçăo das limitaçóes e contingências pela atuaçăo do corpo de Keaton. Mas alguns outros exemplos destacam ainda mais essa questăo. Jean-Philippe Tessé (2007, p. 19) discute um exemplo significativo, da fase em que Keaton ainda trabalhava com Roscoe "Fatty" Arbuckle e ainda estampava alguns sorrisos diante das câmeras: The Garage, de 1920:

[P]risioneiro de uma placa giratória [que estava em funcionamento abaixo dele], Keaton parece, para escapar dela, correr mais rápido do que pode. Ele está além da circunstância (a placa giratória), já no absoluto: para sair da armadilha, ele năo deve ir mais rápido que a armadilha, mas mais rápido que a rapidez, exceder seu próprio corpo ${ }^{15}$. (TESSÉ, 2007, p. 19).

Ser mais rápido que a rapidez, exceder o próprio corpo: temos aqui elementos importantes da manifestaçâo corporal de Buster, que chega aos limites da abstraçấo, do absoluto. Esse ultrapassar dos limites aparece claramente em outro filme, The Cameraman, de 1928, em uma cena descrita por Tessé (2007, p. 27). Morando no último andar de um prédio, Buster espera uma ligaçâo telefônica de sua amada. 0

14 "Much of the pleasure of Keaton's comedy arises from its capacity to reveal the world as not merely a social milieu or a situational locale, but as a physical arena, wherein the body's immediate relation to surrounding topographical features constitutes the primary relation between self and world".

15 «prisonnier d'une plaque tournante qui s'est emballé, il semble pour en réchapper courir plus vite qu'il ne le peut. Il est au-dèla de la circonstance (la plaque tournante), déjá dans l'absolu: pour sortir du piège, il ne feut pas aller plus vite que le piège, mais plus vite que la vitesse, excéder son propre corps ». 
telefone, que fica no térreo, toca. Buster corre para atender, mas descobre que năo era ela. Desapontado, sobe, mas tăo absorto na contemplaçăo de seus pés que ultrapassa seu andar e vai parar no teto. O telefone toca de novo, dessa vez realmente para ele. Empolgado, Buster desce tâo rápido as escadas que ultrapassa agora o térreo, chegando ao subsolo.

Outras formas de corpo-além podem ser encontradas na obra de Keaton. Temos também um corpo que năo apenas se excede em suas açōes, mas que também se multiplica; um corpo que pode se transformar em vários corpos, e ao mesmo tempo. 0 exemplo desse corpo ocorre em uma cena ainda hoje impressionante do filme The Playhouse, de 1921. Acompanhamos na cena um dia de apresentaçóes em um teatro de variedades, mas há um detalhe: todas as pessoas que aparecem na cena săo Buster Keaton. Todas. Maestro, músicos, contrarregra, criança, mulher, senhor, todos săo representados por Buster, que muitas vezes aparece como mais de uma pessoa ao mesmo tempo, graças a trucagens na produçăo. O corpo de Keaton é o corpo de todos; mesmo que a cena seja resultado de um sonho do personagem, seu efeito năo deixa de impactar. Além desse exemplo, gostaria de citar uma cena também bastante marcante do filme Sherlock Jr., de 1924, que traz uma articulaçâo do corpo diferente, mas também resultado de um sonho. Conforme a descriçăo de Tessé:

Sherlock Junior (1925) teoriza de maneira paroxística essa imperiosa plasticidade do espaço em uma cena de trucagem cuja sofisticaçăo técnica, 80 anos mais tarde, surpreende ainda: em seu sonho, Buster penetra uma tela de cinema onde se sucedem planos desconexos de lugares antagonistas (um jardim, o mar, um deserto, uma falésia) entre os quais a continuidade do movimento de seu corpo opera uma ligaçăo imaginária ${ }^{16}$. (TESSÉ, 2007, p. 28).

E esse filme apresenta também outro momento interessante para a discussăo deste artigo: em uma cena posterior, Buster Keaton quase literalmente se transforma em macaco para realizar uma apresentaçâo. Como o animal tinha fugido, Buster o "substitui" para conseguir realizar o número. Essa cena mostra que Buster chega perto de, sem perder sua engenhosidade, transformar-se em outro ser, até um ser náo humanol7. Vemos, com esses exemplos, que o corpo de Buster se excede, multiplica-se, atravessa e liga espaços desconexos. Para o corpo de Keaton, quase nada é impossível. Onde é possível brincar com o espaço, construir formas, ir além da contingência, o corpo de Keaton estará.

\section{CONSIDERAÇÕES FINAIS}

Neste texto, procurei discutir a possibilidade de se relacionar as articulaçôes e manifestaçóes do corpo de Keaton com o campo do pós-humano. Essas articulaçôes foram

16 «Sherlock Junior théorise de manière paroxystique cette impérieuse plasticité de l'espace dans uns scène de trucage dont la sophistication technique, 80 ans plus tard, étonne encore : dans son rêve, Buster pénètre un écran de cinéma où se succèdent des plans déconnectés de lieux antagonistes (un jardin, la mer, un désert, une falaise...) entre lesquels la continuité du mouvent de son corps opère un lien imaginaire ».

17 Algo que Chaplin faz de maneira semelhante no filme Ombro, Armas (Shoulder Arms), de 1918, quando se transforma em árvore para se disfarçar dos inimigos na guerra. 
dividias em três grupos: corpo-com, corpo-entre, e corpo-além. Após a discussăo das cenas, é importante enfatizar que, apesar dessa divisăo, esses grupos dialogam bastante entre si: praticamente todos os exemplos apresentam uma indefiniçăo do corpo de Keaton, uma adaptabilidade, uma maleabilidade. O corpo de Keaton age no mundo em uma contínua abertura às possibilidades, às construçôes no espaço, em diálogo com outros corpos, muitas vezes corpos năo humanos. As fronteiras entre esses elementos se deslocam constantemente: năo sabemos onde começam, onde terminam.

Temos aqui um corpo cronologicamente anterior ao pós-humano, algo como um corpo "pré-pós-humano". Mesmo que anterior, creio que a aproximaçăo entre os dois elementos, corpo de Keaton e pós-humano, é bastante frutífera e produtiva para discussōes e questionamentos. O campo do pós-humano pode colaborar com algumas novas chaves de leitura para a obra de Keaton. A obra de Keaton, por outro lado, caracterizada pela presença de um corpo que dialoga frequentemente com elementos náo humanos, aponta para possíveis raízes, manifestaçōes e caminhos desse corpo pós-humano. 


\section{REFERÊNCIAS}

AUMONT, J.; MARIE, M. Dicionário teórico e crítico de cinema. Traduçāo de Heloísa Araújo Ribeiro. 5. ed. Campinas: Papirus, 2012, p.37.

BAECQUE, A.. Telas: o corpo no cinema. In: COURTINE, J. J. (org.). História do corpo: 3. As mutaçōes do olhar: $O$ século XX. Traduçâo de Ephraim F. Alves. 2. ed. Petrópolis: Vozes, 2008, p. 481-507.

CLAYTON, A. The body i Hollywood Slapstick. Carolina do Norte: McFarland \& Company, 2007.

COUSINS, M. História do cinema: dos clássicos mudos ao cinema moderno. Traduçâo de Cecília Camargo Bartalotti. Sâo Paulo: Martins Fontes, 2013.

FELINTO, E.; SANTAELLA, L. O explorador de abismos: Vilém Flusser e o pós-humanismo. Săo Paulo: Paulus, 2012.

HUNTER, R. A comédia muda. In: KEMP, P. (Org.). Tudo sobre cinema. Traduçăo de Fabiano Morais et al. Rio de Janeiro: Sextante, 2011, p. 62-63.

JULLIER, L.; MARIE, M. Lendo as imagens do cinema. Traduçâo de Magda Lopes. Sáo Paulo: Editora Senac Săo Paulo, 2009.

MICHAUD, Y. Visualizaçôes: o corpo e as artes visuais. In: COURTINE, J. J. (org.). História do corpo: 3. As mutaçôes do olhar: $O$ século XX. Traduçăo de Ephraim F. Alves. 2. ed. Petrópolis: Vozes, 2008, p. 541-565.

SANTAELLA, L. Culturas e artes do pós-humano: da cultura das mídias à cibernética. 2 ed. Săo Paulo: Paulus, 2004.

SMITH, I. H. A general. In: KEMP, P. (Org.). Tudo sobre cinema. Traduçăo de Fabiano Morais et al. Rio de Janeiro: Sextante, 2011, p. 66-67.

TESSÉ, J.-P.. Le burlesque. Paris: Cahiers du cinéma, 2007. 